\title{
Genetically stable plants with boosted flavonoids content after in vitro regeneration of the endangered Capparispinosa L
}

\author{
Goda SM${ }^{1}$, Ahmed $\mathrm{SA}^{1}$, El Sherif $\mathrm{F}^{2,3}$, Hassanean $\mathrm{HA}^{1}$ and Ibrahim $\mathrm{AK}^{* 1}$ \\ ${ }^{1}$ Department of Pharmacognosy, Faculty of Pharmacy, Suez Canal University, Ismailia, Egypt \\ ${ }^{2}$ Department of Horticulture, Faculty of Agriculture, Suez Canal University,Ismailia, Egypt \\ ${ }^{3}$ Department of Biological Sciences,Faculty of Science, King Faisal University, Al-Ahsaa, Kingdom of Saudi Arabia
}

\begin{abstract}
Capparispinosa L. is proven to be a potent hepatoprotective natural remedy. C. spinosa (L.) is a rare species which is on its way to extinction. We herein report an efficient in vitro propagation and regeneration protocol towards effective conservation of this plant. The use of $2 \mathrm{mg} / \mathrm{L} \mathrm{Kinetin} \mathrm{(Kin.)} \mathrm{and} 0.4 \mathrm{mg} / \mathrm{L} 1-\mathrm{naphthalene}$ acetic acid (NAA) on MS basic medium resulted in maximum number of in vitro shoot multiplication and adventitious root formation, respectively. Calli were successfully induced using $2 \mathrm{mg} / \mathrm{L} \mathrm{2,4-} \mathrm{dichloro-phenoxyacetic} \mathrm{acid} \mathrm{(2,4-D).} \mathrm{Direct} \mathrm{organogenesis} \mathrm{from} \mathrm{aerial} \mathrm{part} \mathrm{explants} \mathrm{showed} \mathrm{remarkable} \mathrm{success} \mathrm{using}$ thiadiazurone (TDZ) hormone. Genetic fidelity assessment of the in vitro regenerated plants was confirmed by RAPD analysis. Two-fold increase in flavonoids content than estimated in the wild plants was noticed after elicitation with methyl jasmonate $200 \mu \mathrm{M} / \mathrm{L}$ in 6 - benzyl aminopurine (BAP) pretreated plants as estimated by HPLC. On the other hand, $200 \mu \mathrm{M} / \mathrm{Lmethyl} \mathrm{jasmonate} \mathrm{boosted} \mathrm{the} \mathrm{flavonoids} \mathrm{concentration} \mathrm{by} 1.5$ fold in Kin pretreated plants. This work could be considered as a regular platform for conservation of this endangered plant guaranteeing regenerates of genetic high fidelity and improved chemical profile.
\end{abstract}

\section{Introduction}

Capparis spinosa L.F. Capparidaceae is used around the world for many pharmacologicalpurposes. The hepatoprotective effectof $C$. spinosa L. was explained based on its antioxidant activity [1]. Capers are used for treatment of gout by inhibitionthe synthesis of uric acid [1]. Also, they are beneficial for asthmatic patients duetoantagonist effect forsmooth muscle contraction in rat trachea [2]. Many phytochemicals were identified from C. spinosa like flavoniods and their glycosides [3]. Quercetin, isoquercetin and rutin flavonoids had anti- $\mathrm{H}_{5} \mathrm{~N}_{1}$ viral activity [4]. C. spinosa $\mathrm{L}$. is considered as an endangered plant in North Sinai, Egypt [5]. Despite its medicinal importance, only few studies have been concerned with its propagation [6]. A micropropagation protocolwas introduced for Lebanese C. spinosa subsp Rupestris using $1 \mathrm{mg} / \mathrm{L}$ zeatin, then the shoots rooted with IAA [7]. While, a regeneration protocol was introduced forC. spinosa L. subsp. Rupestris in Italy from flowerexplant with $13 \mu \mathrm{M}$ BAP [8]. The main objective of this study was to develop a protocol for an in vitro micropropagation; using shoot tip explant and a regeneration system; using leaf, root or stem segments of C. spinosa L. from North Sinai with a stablegenetic profile and better bioactive flavonoids yield towards the conservation of this medicinally active species.

Elicitation is considered as an effective strategy for many biomedicinals production. It initiatesor accelerates biosynthetic pathways of secondary metabolites when applied at small concentrations. The plants produce secondary metabolites as a defense mechanism against attack by any pathogens. Biotic elicitors of biological origin and abiotic elicitors were used [9].

To confirm genetic fidelity of regenerate plants to mother plant, Random AmplifiedPolymorphic DNA (RAPD) can be done. RAPD is a useful tool due to its speed and simplicity in addition to a random primer can anneal at many locations of genome to produce its DNA fingerprint [10].

\section{Material and methods}

Seed sterilization and germination: Ripe fruits were collected in May 2014, from wild plants of the natural places in St. Katherine Protectorate, Egypt. The seeds were extracted from the fruitsand sterilized according to previously reported sterilization protocol [11]. Surface sterilized seeds were cultured in $10 \mathrm{~mL}$ of half strength Murashige and Skoog (MS) basic salts and vitamins medium (Murashige and Skoog, 1962) supplemented with, 3\% sucrose and 6.0 $\mathrm{g} / \mathrm{L}$ agar within a $40 \mathrm{~mL}$ capacity jar. The medium $\mathrm{pH}$ was adjusted to 5.7 before autoclaving for 20 minutes at $121^{\circ} \mathrm{C}$. A total of one hundred jars were inoculated with one seed per jar. The culture jar were incubated in a growth room maintained at $22 \pm 2^{\circ} \mathrm{C}$, illuminated with Phillips TLM 40W/33RS fluorescent lamp providing 4000 Lux light intensity for 16 hrs a day. The germination percentage was determined 12 weeks from the inoculation date.

Effect of cytokinins on shoot proliferation: Eight weeks old shoot tips $(0.5-1 \mathrm{~cm}$ height $)$ were excised from the in vitro seedlings and

Correspondence to: Amany K Ibrahim, Department of Pharmacognosy, Faculty of Pharmacy, Suez Canal University, Ismailia, Egypt, E-mail: am_kamal66@yahoo.com

Key words: HPLC analysis, in vitro regeneration, methyljasmonate elicitor, RAPD analysis

Received: January 30, 2017; Accepted: February 22, 2017; Published: February 26,2017 
transferred to a $200 \mathrm{~mL}$ jar with $30 \mathrm{ml}$ of strength Murashige and Skoog (MS) basic salts and vitamins mediumsupplemented with, $3 \%(\mathrm{w} / \mathrm{v})$ of sucrose and $6 \mathrm{~g} / \mathrm{L}$ agar. The $\mathrm{pH}$ of the medium was adjusted to 5.7 by $1 \mathrm{~N}$ of $\mathrm{NaOH}$ or $\mathrm{HCl}$ and autoclaved as described above. Filter-sterilized benzyl aminopurine (BAP) or 2- isopentyl adenine (2iP) or Kinetin (Kin.) at the concentration of $0.0,2.0,4.0$ and $6.0 \mathrm{mg} / \mathrm{L}$ was added to the media after it was autoclaved.Each treatment consisted of 10 jars each withtwo explants. The incubation conditions were as described for the in vitro seedlings above.After 5 weeks of culture, the number of shoots, plant height and plant weight were recorded. Multiple shoots were collected and dried at room temperature, and active compounds were extracted with methanol to perform High Performance Liquid Chromatography (HPLC) analysis.

In vitro adventitious root formation: Seventeen weeks old micro shoots $(0.5-1 \mathrm{~cm}$ height) were sub-cultured onto MS medium supplemented with different concentrations of indole-3-butyric acid (IBA), indole-3-acetic acid (IAA) or 1- naphthalene acetic acid (NAA) at $0.0,0.1,0.2$ and $0.4 \mathrm{mg} / \mathrm{L}$. Each treatment consisted of 10 jars and each jar containing two explants. Culture conditions were as described above. The number of roots per initial micro shoot, maximum root length, number of new shoots, plant fresh weight as well as maximum shoot length after 6 weeks. Rooted explants samples were collected, dried at room temperature and extract with methanol to perform HPLC analysis.

Acclimatization: Four well rooted in vitro plantlets were removed from the culture medium, washed in tap water to remove agar from cultured media and immersed in $1 \%$ of rizolex $^{\circledR}$ fungicide for 10 minutes. The rooted plantlets were transferred to the greenhouse for acclimatization in pots with a moist sand. The plants were irrigated with fine water mist for 3 weeks inside a growth chamber. After 4 weeks, the percentage of the survived plants was recorded. Acclimated plants samples were collected, dried at room temperature and extract with methanol to perform HPLC analysis.

Callus induction: Leaf explants of $0.5-1 \mathrm{~cm}$ length were placed on a solid agar medium. The culture media consisted of the mineral salts of MS supplemented with 2,4- dichloro-phenoxyacetic acid (2,4-D) at the concentration of $0.5,1,2,4$ and $6 \mathrm{mg} / \mathrm{L}$ [12]. Each treatment consists of 8 replicates with 4 leaf explants of $0.5-1 \mathrm{~cm}$ length for each sample. The culture conditions were as described above. The callus weight, callus color, number of roots as well as root length were recorded after 4 weeks. The leaf samples from callus were collected, dried at room temperature and extract with methanol to perform HPLC analysis.

Plant regeneration and organogenesis:MS basal medium supplemented with $3 \%(\mathrm{w} / \mathrm{v})$ sucrose and $6 \mathrm{~g} / \mathrm{L}$ of agar was prepared and the $\mathrm{pH}$ of the medium was adjusted to 5.8 by $1 \mathrm{~N} \mathrm{NaOH}$ or $\mathrm{HCl}$ prior to autoclaving at $121^{\circ} \mathrm{C}$ and $1.2-1.3 \mathrm{Kg} / \mathrm{Cm}^{2}$ pressure for 20 minutes. Filter sterilized thiadiazurone (TDZ) at the concentration of $0.0,110,220$ and $440 \mathrm{mg} /$ Lwere added to the $46^{\circ} \mathrm{C}$ autoclaved medium temperature of the media. Each treatment consisted of 10 petri dishes $(9$ $\mathrm{cm}$ in diameter) with $30 \mathrm{ml}$ of medium. The aerialpart of $1 \mathrm{gm}$. weight was cut into very small pieces with $2 \mathrm{ml}$ sterile distilled water by scalpel and cultured on petridishes containing TDZ hormone-incorporated media [13]. The culture conditions were as described above. After 15 days, a successful regeneration was observed and the number of regenerated shoots per explants and also their length were recorded. Different selected lines of the regenerated plants were sub-cultured on MS medium supplemented with $2 \mathrm{mg} / \mathrm{L}$ BAP for multiplication. After 4 weeks, the samples of the different lines of regenerated plants were collected, dried at room temperature and extracted with methanol to perform HPLC analysis.Another fresh samples were kept to be examined bythe RAPD analysis.

Statistical analysis for in vitro micropropagation protocol: Experiments were set up in completely randomized design. Data were statistically analyzed using CoStat version 6.303 1998-2004 CoHort software 798 Lighthouse Ave PMP 320, Monterey, CA, 93940, USA. Analysis of variance (ANOVA) was performed to compare results. Least significance difference (LSD) test was used to compare means at the $5 \%$ significance level.

\section{Genetic assessment}

Genomic DNA extraction:DNA was extracted from fresh leaves from four lines of the in vitro regenerated plantlets as well as control plants using a CTAB protocol [14] and DNA concentration was determined by measuring $\mathrm{OD}_{260}$ at $260 \mathrm{~nm}$ wave length using NanoDrop (ND-1000 spectrophotometer).

Random amplified polymeric DNA (RAPD): A set of ten random primers (Table 1) was used in the detection of polymorphism among the regenerated plantlets and control. RAPD-PCR was carried out in $25 \mu \mathrm{l}$ reaction volume containing $12.5 \mu \mathrm{L}$ Master Mix (Qiagen), $2 \mu \mathrm{L}$ primer $(20$ pmole), $2 \mu \mathrm{L}$ templates DNA of concentration $(20 \mathrm{ng} / \mu \mathrm{L})$ and $8.5 \mu \mathrm{L}$ water nuclease free.

Thermo cycling profile and determination of PCR products: PCR amplification was performed in a C1000- Thermo cycler (Master cycler gradient eppendorf) programmed to fulfill 40 cycles after an initial denaturation cycle for $5 \mathrm{~min}$ at $94^{\circ} \mathrm{C}$. Each cycle consisted of a denaturation step at $94^{\circ} \mathrm{C}$ for 30 seconds, an annealing step at $40^{\circ} \mathrm{C}$ for 30 seconds, and an elongation step at $72^{\circ} \mathrm{C}$ for 30 seconds. A final extension step ofwas performed at $72^{\circ} \mathrm{C}$ for $7 \mathrm{~min}$. The amplification products were resolved by electrophoresis in a $1.5 \%$ agarose gel containing ethidium bromide $(0.5 \mu \mathrm{g} / \mathrm{ml})$ in $1 \mathrm{X}$ TAE buffer $(45 \mathrm{mM}$ Tris borate, $1 \mathrm{mM}$ EDTA) at 95 volts. PCR products were visualized on UV light and photographed. Amplified products were visually investigated by presence or absence of the bands.

Capillary electrophoresis: DNA fragments (four lines of the in vitro regenerated plantlets as well as control plants) were analyzed in the automatic multicapillary electrophoresis (QIAxcel-QIAGEN). Isolated DNA was placed in the instrument sample tray, $10 \mathrm{ml}$ of the DNA samples were automatically injected into the capillary channel and subjected to electrophoresis according to the protocol AM420 (method separation time: $420 \mathrm{~s}$, method injection time: 10s, method separation voltage: $5.0 \mathrm{kV}$ and method injection voltage: $5.0 \mathrm{kV}$ ) of the

Table 1. Sequence of 10 different random primers used for RAPD analysis of control and in vitro regenerated plants of Capparis spinosa L.

\begin{tabular}{|c|c|c|c|}
\hline Name & Sequence (5'-3') & Name & Sequence (5'-3') \\
\hline OPA-1 & 5'CAGGCCCTTC3' & OPk-3 & 5' \\
\hline OPA-3 & 5'AGTCAGCCAC3' & OPk-12 & 5'TGG-11 \\
\hline OPA-11 & 5'CAATCGCCGT3' & OPOCTTAGG3' & 5'GACAGGAGGT3' \\
\hline OPA-15 & 5'TTCCGAACCC3' & OPO-15 & 5'TGGCGTCCTT3' \\
\hline OPk-2 & 5'GTCTCCGCAA3' & OPO-20 & 5'ACACACGCTG3' \\
\hline
\end{tabular}




\section{QIAxcel DNA Screening Kit.}

Extraction of phytochemicals from in vitro cultured plants: The weighed samples were soaked separately in absolute ethanol for 4 days. Sonication for 30 minutes was done to aid extraction process of the active compounds. The whole process of soaking, sonication and filtration was repeated for 5 times and the supernatant was filtered prior to drying at room temperature. Finally, the weight of viscous ethanolic extract of each sample was determined.

\section{HPLC analysis}

Preparation of standard and sample solutions for HPLC: Standard solutions of rutin were prepared in methanol of HPLC grade at a concentration range of 0.01625 to $1 \mathrm{mg} / \mathrm{ml}$ for rutin. The plant extract samples were dissolved in methanol HPLC at concentration 1 $\mathrm{mg} / \mathrm{ml}$ then filtered through a $0.22 \mu \mathrm{mChrom}$ tech ${ }^{\circledR}$ Nylon syringe filter (Millipore). Triplicate injections were made and a linear regression was generated at wavelength of $257 \mathrm{~nm}$.

Chromatographic method: Chromatographic analysis was carried out in isocratic conditions and at room temperature using reversed phase-C18 column $(4.6 \mathrm{~mm} \times 250 \mathrm{~mm})$ packed with $5 \mu \mathrm{m}$ diameter particles and Thermo - Dionex ${ }^{\circledR}$ HPLC Model Ultimate 3000. The mobile phase was methanol-acetonitrile- water $(25: 15: 60, \mathrm{v} / \mathrm{v} / \mathrm{v})$ containing $1.0 \%$ glacial acetic acid. The mobile phase was filtered through a $0.45 \mu \mathrm{m}$ Nylon membrane filter and degassed in ultrasonic bath for 15 minutes previous to use. Flow rate and injection volume were $1.0 \mathrm{ml} / \mathrm{min}$ and $10 \mu \mathrm{l}$, respectively. The chromatographic peaks were identified by comparing their retention time and UV spectra with the reference standard at wave length $257 \mathrm{~nm}$. Quantification was carried out by the integration of each peak using the external standard method.

\section{Elicitation}

Chemical feeding (Abiotic elicitors): Four weeks old in vitro micro shoots from both Kin and BAP media were sub-cultured into 40

Table 2. Chemical feeding with different concentration of sodium chloride, and sodium salicylate.

\begin{tabular}{|c|c|}
\hline Abiotic elicitors & Concentration \\
\hline Sodium chloride & $25 \mathrm{mM}$ \\
\hline Sodium chloride & $50 \mathrm{mM}$ \\
\hline Sodium salicylate & $5 \mathrm{mg} / \mathrm{L}$ \\
\hline Sodium salicylate & $10 \mathrm{mg} / \mathrm{L}$ \\
\hline Sodium salicylate & $20 \mathrm{mg} / \mathrm{L}$ \\
\hline
\end{tabular}

$\mathrm{ml}$ capacity jars containing $10 \mathrm{ml}$ MSmedium containing full strength basic salts and vitamins. The medium was supplemented with $3 \%(w / v)$ sucrose, $6.0 \mathrm{~g} / \mathrm{L}$ agar and one of the following chemical elicitors (Table 2 ), the $\mathrm{pH}$ was adjustedto 5.7 prior to autoclaving [15].

Another abiotic elicitor, methyl jasmonate (MeJA), was tested. MeJA was dissolved in ethanol in order to prepare a stock solution. Filter-sterilized MeJA was added at concentrations of 20, 50, 100 and $200 \mu \mathrm{M} / \mathrm{L}$ to autoclaved MS medium containing full strength basic salts and vitamins, $3 \%(\mathrm{w} / \mathrm{v})$ sucrose and $6.0 \mathrm{~g} / \mathrm{L}$ agar prior to dispersion into petridishes of $9 \mathrm{~cm}$ in diameter [16]. All elicited samples were collected and extracted to be ready for quantitative determination by HPLC analysis method after 15 days from their culture.

Fungal feeding (biotic elicitors):Two fungal cultureswere used; Aspergillus niger NRRL 3 and Rhizopusstolonifer NRRL 1472. The fungi were cultured in $500 \mathrm{ml}$ flasks containing $150 \mathrm{ml}$ medium and were shaken at $30^{\circ} \mathrm{C}$ and $150 \mathrm{rpm}$ on an incubator shaker, Innova ${ }^{\circledR}$ 43 incubator shaker series. The liquid medium composition was as follows in $\mathrm{g} / \mathrm{L}$ : glucose, 30 ; ammonium nitrate, 2.5 ; sodium dihydrogen phosphate, 1; magnesium sulfate. $7 \mathrm{H}_{2} \mathrm{O}, 0.25$ and zinc sulfate $7 \mathrm{H}_{2} \mathrm{O}$, 0.05 . The cells of Aspergillus niger NRRL 3 were harvested after 21 days cultures while Rhizopusstolonifer NRRL 1472 after 45 days culture.The harvested fungal cultures werethen, autoclaved, filtered and ground using a mortar. Dry powders were added in concentration of $80 \mathrm{mg} / \mathrm{L}$ [15].

Statistical analysis for HPLC assessment and elicitation process: Statistical analysis using SPSS (Statistical package for social science) version 16 , software package for data analysis was done. The quantitative data were presented in the form of mean \pm SD using $p=0.05$. The test of significance is one way ANOVA was used to compare between the means.

\section{Results and discussion}

In vitro shoot proliferation:The MS medium supplemented with $2.0 \mathrm{mg} / \mathrm{L}$ kinetinprovided the maximum number for in vitro shoot proliferation (5.364 shoots/explant) (Table 3) (Figure 1A). The more the concentrationthan $2 \mathrm{mg} / \mathrm{L}$ kinetin, the less the number of the propagated shoots. On the other hand, MS medium supplemented with $4.0 \mathrm{mg} / \mathrm{L}$ kinetin provided the longest one of the propagated shoots $(2.455 \mathrm{~cm})$. Based on these findings,kinetin is supposed to be the most efficient growth regulator tested for the optimal multiplication of this plant material.Previous studies on Lebanese C. spinosa subsp Rupestris reported that the maximum shoot number (4.8 shoots/explants) was provided using woody plant medium (WPM) supplemented with1.6 $\mathrm{mg} / \mathrm{L}$ zeatin [16]. Similar results were reported forother plants. The

Table 3. Effects of 6- benzyl aminopurine (BAP), 2- isopentyladenine (2iP) and kinetin (Kin) concentrations on plant height, fresh weight, number of shoots per explants and callus weight of Capparis spinosa L.

\begin{tabular}{|c|c|c|c|c|c|c|}
\hline \multicolumn{3}{|c|}{ Growth regulator (mg/L) } & \multirow[t]{2}{*}{ Length of the longest shoot $(\mathrm{cm})$} & \multirow[t]{2}{*}{ Explant's fresh weight (g.) } & \multirow[t]{2}{*}{ No. of shoots/explant } & \multirow[t]{2}{*}{ Callus weight (g.) } \\
\hline BAP & $2 \mathrm{iP}$ & Kin. & & & & \\
\hline 0.0 & 0.0 & 0.0 & $2.12^{\mathrm{ab}}$ & $0.31^{\mathrm{b}}$ & $2.86^{\mathrm{c}}$ & $0^{\mathrm{c}}$ \\
\hline 2.0 & 0.0 & 0.0 & $1.36^{\mathrm{c}}$ & $0.53 \mathrm{a}^{\mathrm{b}}$ & $3.39^{\mathrm{bc}}$ & $0.09^{\mathrm{abc}}$ \\
\hline 4.0 & 0.0 & 0.0 & $1.29^{\mathrm{c}}$ & $0.59^{\mathrm{a}}$ & $4.75^{\mathrm{a}}$ & $0.10^{\mathrm{abc}}$ \\
\hline 6.0 & 0.0 & 0.0 & $1.31^{\mathrm{c}}$ & $0.69^{\mathrm{a}}$ & $4.83^{\mathrm{a}}$ & $0.18^{\mathrm{a}}$ \\
\hline 0.0 & 2.0 & 0.0 & $1.91^{\mathrm{abc}}$ & $0.56^{\mathrm{ab}}$ & $4.50^{\mathrm{ab}}$ & $0.04 b^{c}$ \\
\hline 0.0 & 4.0 & 0.0 & $1.75^{\mathrm{bc}}$ & $0.57^{\mathrm{ab}}$ & $4.64^{\mathrm{a}}$ & $0.03 b^{c}$ \\
\hline 0.0 & 6.0 & 0.0 & $2.36^{\mathrm{ab}}$ & $0.69^{\mathrm{a}}$ & $4.57^{\mathrm{a}}$ & $0.14^{\mathrm{ab}}$ \\
\hline 0.0 & 0.0 & 2.0 & $2.14^{\mathrm{ab}}$ & $0.60^{\mathrm{a}}$ & $5.36^{\mathrm{a}}$ & $0.15^{\mathrm{ab}}$ \\
\hline 0.0 & 0.0 & 4.0 & $2.46^{\mathrm{a}}$ & $0.62^{\mathrm{a}}$ & $4.46^{\mathrm{ab}}$ & $0^{c}$ \\
\hline 0.0 & 0.0 & 6.0 & $1.28^{\mathrm{c}}$ & $0.53^{\mathrm{ab}}$ & $3^{c}$ & $0.02^{\mathrm{bc}}$ \\
\hline
\end{tabular}

(Note: Means with the similar letters are not significantly different at 0.05 level of probability using LSD test. $\mathrm{n}=12$ ). 
best shoot propagation and plantlets lengthfor Gerbera jamesonii were obtained from medium containing MS supplemented by $2 \mathrm{mg} / \mathrm{L}$ Kin [17]. Fotso and coworkers havereported that kinetin was combined with BAPfor best results for micropropagation of Swieteniamacrophylla [18].

In vitro root formation: The NAA was found to be more effective than IAA and IBA in robust roots induction fromshoot cultures (Table 4). Of the tested concentrations range, $0.4 \mathrm{mg} / \mathrm{L}$ NAA resulted in the maximum number of roots (13.18 roots/explant) (Figure 1B), while the longest one was obtained from MS medium supplemented with $0.2 \mathrm{mg} / \mathrm{L}$ NAA.The ascendance in NAA concentrations resulted in more adventitious root formation. Pardo reported that an increase in NAA concentration during the in vitro cultivation of Billbergiarosea is concordant with increasein the number of roots of in vitro cultivated Billbergiarosea [19]. Our results are similar to study of Citrus megaloxycarpa as the maximum number of roots was produced with $2 \mathrm{mg} /$ LNAA [20].

Acclimatization:Almost $75 \%$ of the in vitro rooted plants showed remarkable success in accommodation with external field conditions (Figure 1C).

Callus induction: Table 5 discussed the effect of different concentrations of 2,4-D on callus weight when initiated from leaf explants. It also showed that callus initiation was successfully established at all concentrations of that hormone after 4 weeks with no difference between them but neither rooting nor shooting had occurred. The highest weight of brownish white callus was obtained from MS medium supplemented by $2 \mathrm{mg} / \mathrm{L}$ 2,4- D (Figure 1D). Many

Table 4. Effects of Indole-3-acetic acid (IAA), Indole-3-butyric acid (IBA) and 1naphthalene acetic acid (NAA) concentrations on number of roots, root length and rooting percentage of Capparis spinosa L.

\begin{tabular}{|l|l|l|c|c|c|c|}
\hline \multicolumn{3}{|l|}{$\begin{array}{l}\text { Growth regulator } \\
\text { (mg/L) }\end{array}$} & $\begin{array}{c}\text { Plant's } \\
\text { height } \\
\text { (cm) }\end{array}$ & $\begin{array}{c}\text { Plant's fresh } \\
\text { weight (g.) }\end{array}$ & $\begin{array}{c}\text { No. of roots/ } \\
\text { explant }\end{array}$ & $\begin{array}{c}\text { Length of the } \\
\text { longest root } \\
\text { (cm) }\end{array}$ \\
\cline { 1 - 3 } IBA & IAA & NAA & & & & \\
\hline 0.0 & 0.0 & 0.0 & $5.46^{\mathrm{ab}}$ & $1.09^{\mathrm{a}}$ & $1.55^{\mathrm{b}}$ & $0.32^{\mathrm{c}}$ \\
\hline 0.1 & 0.0 & 0.0 & $4.75^{\mathrm{abc}}$ & $1.03^{\mathrm{a}}$ & $1.60^{\mathrm{b}}$ & $1^{\mathrm{bc}}$ \\
\hline 0.2 & 0.0 & 0.0 & $4.54^{\mathrm{bcd}}$ & $0.91^{\mathrm{a}}$ & $4.67^{\mathrm{b}}$ & $0.46^{\mathrm{bc}}$ \\
\hline 0.4 & 0.0 & 0.0 & $3.28^{\mathrm{d}}$ & $0.96^{\mathrm{a}}$ & $7.14 \mathrm{a}^{\mathrm{b}}$ & $1.14^{\mathrm{abc}}$ \\
\hline 0.0 & 0.1 & 0.0 & $4^{\mathrm{cd}}$ & $0.97^{\mathrm{a}}$ & $4.78^{\mathrm{b}}$ & $0.50^{\mathrm{bc}}$ \\
\hline 0.0 & 0.2 & 0.0 & $5.27^{\mathrm{ab}}$ & $1.08^{\mathrm{a}}$ & $2.27^{\mathrm{b}}$ & $0.41^{\mathrm{c}}$ \\
\hline 0.0 & 0.4 & 0.0 & $5.55^{\mathrm{ab}}$ & $1.28^{\mathrm{a}}$ & $2.36^{\mathrm{b}}$ & $0.23^{\mathrm{c}}$ \\
\hline 0.0 & 0 & 0.1 & $5.73^{\mathrm{a}}$ & $0.94^{\mathrm{a}}$ & $1.73^{\mathrm{b}}$ & $1.14^{\mathrm{abc}}$ \\
\hline 0.0 & 0 & 0.2 & $5.25^{\mathrm{abc}}$ & $0.88^{\mathrm{a}}$ & $8.38 \mathrm{a}^{\mathrm{b}}$ & $2.5^{\mathrm{a}}$ \\
\hline 0.0 & 0 & 0.4 & $4.82^{\mathrm{abc}}$ & $1.01^{\mathrm{a}}$ & $13.18^{\mathrm{a}}$ & $1.73^{\mathrm{ab}}$ \\
\hline
\end{tabular}

(Note: Means followed by the same letter within a column are not significantly different at 0.05 level of probability according to L.S.D. test. $\mathrm{n}=10$ ).

Table 5. Effect of different concentrations of 2,4- dichloro- phenoxy acetic acid (2,4-D) on callus weight from leaf explants of Capparis spinosa $\mathrm{L}$.

\begin{tabular}{|c|c|l|}
\hline $\begin{array}{c}\text { Concentrations of } \\
\mathbf{2 , 4 - D}(\mathbf{m g} / \mathbf{L})\end{array}$ & Callus weight (g.) & Callus colour \\
\hline 0.5 & $0.08^{\mathrm{a}}$ & Brownish white \\
\hline 1 & $0.07^{\mathrm{a}}$ & Brownish white \\
\hline 2 & $0.11^{\mathrm{a}}$ & Brownish white \\
\hline 4 & $0.10^{\mathrm{a}}$ & Brownish white \\
\hline 6 & $0.07^{\mathrm{a}}$ & Brownish white \\
\hline 8 & $0.06^{\mathrm{a}}$ & Brownish white \\
\hline
\end{tabular}

(Note: Means followed by the same letter within a column are not significantly different at 0.05 level of probability according to L.S.D. test).

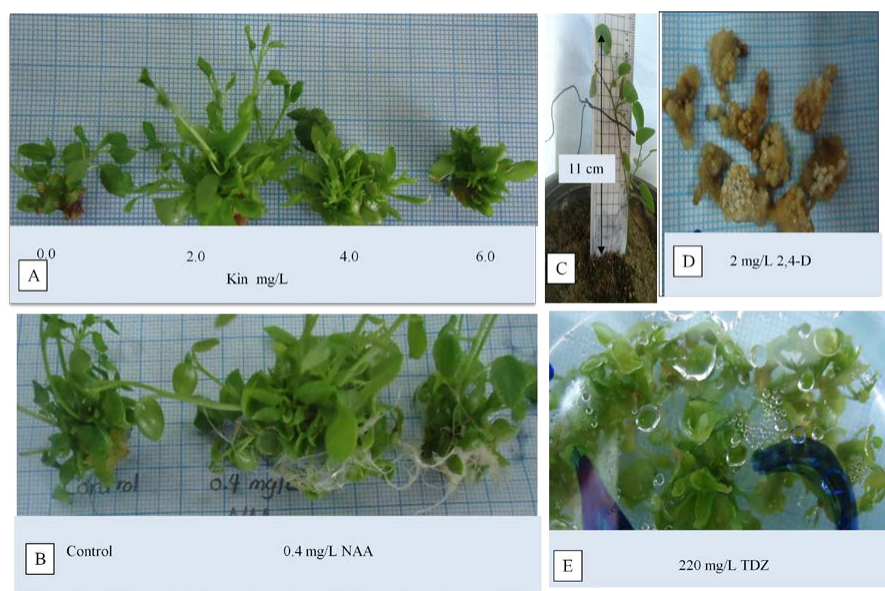

Figure 1. (A) shoot proliferation of Capparis spinosa $\mathrm{L}$. on MS medium containing $2 \mathrm{mg} / \mathrm{L}$ $\mathrm{Kin},(\mathbf{B})$ adventitious root formation on MS medium with $0.4 \mathrm{mg} / \mathrm{L}$ of NAA, (C) $E X$ vitro acclimatized plants at external field conditions, (D) Effect of MS medium with 2,4-D at 2 $\mathrm{mg} / \mathrm{L}$ on leaf callus and (E) plant organogenesis from mashed aerial part on MS medium with $220 \mathrm{mg} / \mathrm{L}$ TDZ.

researchers reported that 2,4-D isthe best auxin for callus induction [21]. Three $\mathrm{mg} / \mathrm{L} 2,4-$ Dsucceeded in callus induction in Solanum tuberosum L. from leaf and shoot tipexplants [22].

Plant regeneration and organogenesis: Direct organogenesis from aerial part explants showed remarkable success in Capparisspinosa L. There was no difference between different concentrations of TDZ hormon on the number of regenerated plants, while there was signifcant difference between $110 \mathrm{mg} / \mathrm{L}$ and both 220 and $440 \mathrm{mg} / \mathrm{L}$ of TDZ hormon on the length of regenerated plants (Table 6) (Figure $1 \mathrm{E})$. Direct regeneration is an effective route for production of plantlets with a low risk of any genetic aberration. Other reports proved that TDZ induces shoot induction better than other cytokinins in plant tissue culture [23-24]. Also, Faisal and Anisreported the effectiveness of TDZ at lower concentration for multiple shoot induction in Rauvolfiatetraphylla L [25].

RAPD analysis: RAPD was performed to analyze the genetic stability of four in vitro regenerated plants of a random selection manner as well as control plant using four random primers. Out of ten random primers, four primers succeeded to develop high amplification (Table 7). Figure 2 (A,B,C and D) showed the similar bandingpatternsbetween control and random in vitro regenerated plants that puts an emphasis on that the clonal propagation was developed with low risk of somaclonal variation or any genetic aberration in regenerated plant. Genetic assessment of the in vitro regenerated plants by RAPD markers has been reported [26-27]. Bhowmik [28] reported genetic uniformity of in vitro micropropagated of Mantisiaspathulata using RAPD analysis. Also, all banding profiles from regenerated plants of Alpiniagalanga $\mathrm{L}$ were similar to the mother plant [29].

HPLC analysis:The rutin standard calibration curve was constructed according to equation of $\mathrm{y}=25.21 \mathrm{X}+0.061$ and regression $\mathrm{R}^{2}=0.998$ at retention time 3.4 minutes using mobile phase; methanolacetonitrile- water $(25: 15: 60, \mathrm{v} / \mathrm{v} / \mathrm{v})$ containing $1.0 \%$ acetic acid glacial at $257 \mathrm{~nm}$ (Figure $3 \mathrm{~A}$ ).

HPLC analysis for in vitro propagated plants: Peak purity was assessed by comparing the response of total flavonoids content at 257 $\mathrm{nm}$ (UV maximum and $275 \mathrm{~nm}$, over time. Only one sharp peak for total flavonoids content appeared on the two wavelengths. The absorbance ratio that expressed by dividing the slice area at wavelength 257 by 
Table 6. Effect of different concentrations of thiadiazurone (TDZ) on the number of regenerated plants and their length in Capparis spinosa $\mathrm{L}$.

\begin{tabular}{|c|c|c|}
\hline TDZ (mg/L) & No. of regenerate plants & Regenerate Plant's length (cm) \\
\hline 110 & $16^{\mathrm{a}}$ & $0.51^{\mathrm{b}}$ \\
\hline 220 & $19^{\mathrm{a}}$ & $1.50^{\mathrm{a}}$ \\
\hline 440 & $18^{\mathrm{a}}$ & $2^{\mathrm{a}}$ \\
\hline
\end{tabular}

(Note: Means followed by the same letter within a column are not significantly different at 0.05 level of probability according to L.S.D. test).

Table 7. Sequence of 4 different random primers used for RAPD analysis of control and regenerated plants of Capparis spinosa $\mathrm{L}$.

\begin{tabular}{|c|c|c|c|}
\hline Name & Sequence (5'-3') & Name & Sequence (5'-3') \\
\hline OPA-1 & 5'CAGGCCCTTC3' & OPA-11 & 5'CAATCGCCGT3' \\
\hline OPA-3 & 5'AGTCAGCCAC3' & OPA-15 & 5'TTCCGAACCC3' \\
\hline
\end{tabular}
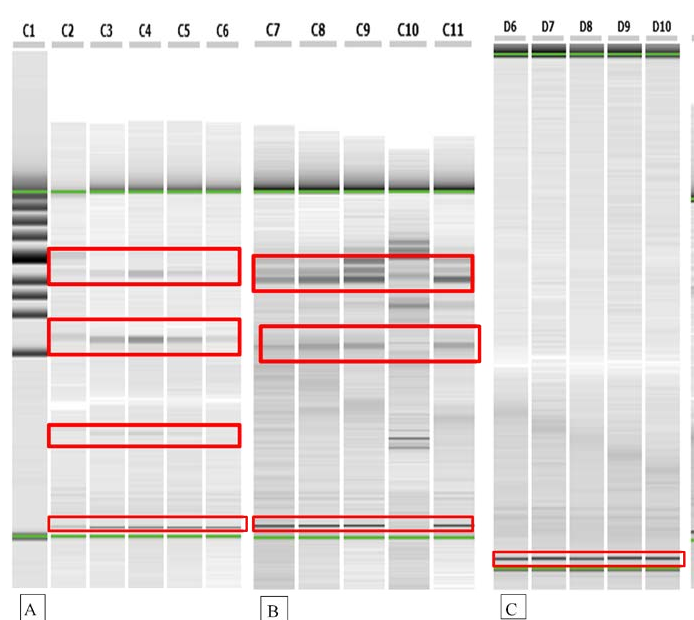

C

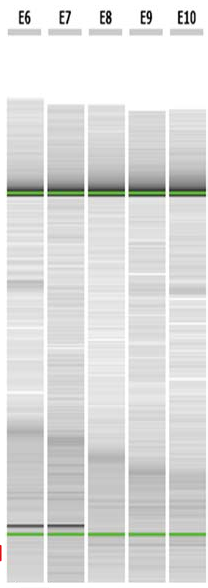

D

Figure 2 (A, B, C and D). RAPD pattern of control and regenerated plants of Capparis spinosa L. C1: Size marker, C2: control, C3-C6: 4 samples for Primer (PA1); C7: control, C8-C11: 4 samples for primer (PA3); D6: control, D7-D10: 4 samples for primer (A11) and E6: control, E7-E10: 4 samples for primer (A15). the slice area of the other wavelength 275 was constant throughout all corresponding slices of the peaks [30-32]. From our study, wild plants showed the highest total flavonoids content calc. as rutin $(3.35 \pm 0.15 \%$ $\mathrm{W} / \mathrm{W}$ ) (Table 8 ). All in vitro treatments and control groups have shown a decline inthe total flavonoids content. Acclimatization or the transfer of thein vitro rooted plantlets from the rooting media to natural external field conditions was shown to increase the total flavonoids content to $2.35 \pm 0.07 \% \mathrm{~W} / \mathrm{W}$. The maximum total flavonoids content as rutin $(1.73$ $\pm 0.14 \% \mathrm{~W} / \mathrm{W}$ )was obtained from BAP- treated plants among different in vitro propagated plants (Figure $3 \mathrm{~B}$ ). Both treatments with highest total flavonoids content (BAP and Kin.) were selected to be exposed to elicitation to improve their total flavonoids content. The previous results confirmed that plant growth regulators play an essential role in phytochemicals production better than control plants [33]. They can enhance flavonoid production, as shown for stimulation of apigenin and luteolin production by BAP application on Arnica Montana [34], Also, stimulation of quercetin, catechin and myricetin production was also reported for Cyperusrotundus [35].

HPLC analysis for different tested elicitors inCapparisspinosa L.samples pretreated with BAP: It is apparent that MeJA (methyl jasmonate) elicitor has a stunning effect on the total flavonoids content (Table 9). The more the concentration of MeJA, the more the flavonoids content in the tested concentration range. The highest flavonoids content was obtained with $200 \mu \mathrm{M} / \mathrm{LMeJA}$ which was twofold that estimated in the wild plants. On the other side, increased concentrations of sodium chloride decreased the flavonoids content. Fungal elicitation, with Aspergillus niger NRRL 3, Rhizopusstolonifer NRRL 1472, and sodium salicylate chemical elicitor was found to affect negatively on the flavonoids accumulation within the tested range. Also, Ghasemzadeh and Jaafar [36] reported decline in flavonoids concentrations as quercetin in responsetosalicylic acid treatment $\left(10^{-5}\right.$ $\mathrm{M}$ and $10^{-3} \mathrm{M}$ ) that inhibits the activity of PAL enzyme, a master key in the flavonoids biosynthesis.

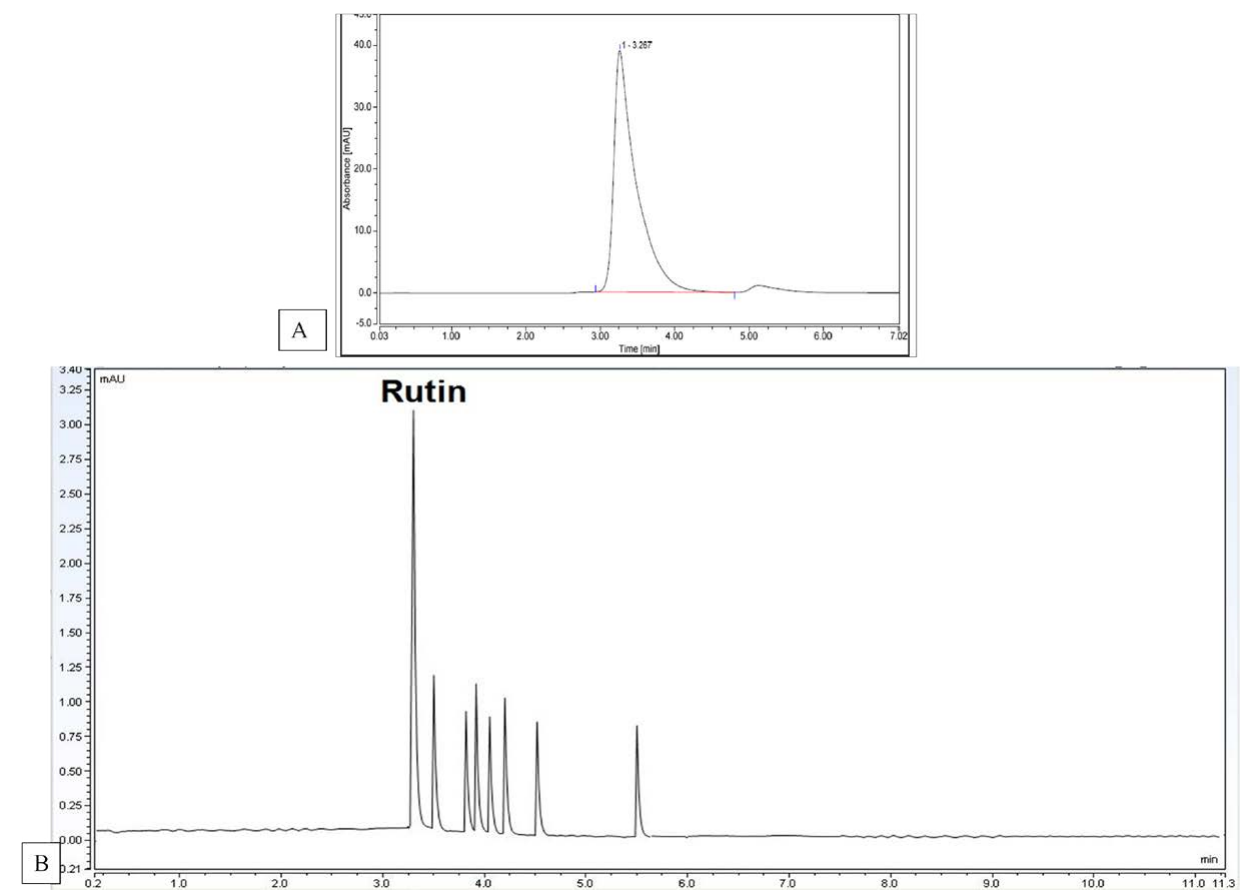

Figure 3. (A) HPLC chromatogram of standard rutin and (B) HPLC chromatogram of BAP- treated plants at retention time 3.4 minutes using mobile phase methanol-acetonitrile- water $(25: 15: 60, \mathrm{v} / \mathrm{v} / \mathrm{v})$ containing $1.0 \%$ acetic acid glacial at $257 \mathrm{~nm}$. 
Table 8. The concentration of total flavonoids calculated as rutin corresponding to different in vitro media manipulations in Capparis spinosa $\mathrm{L}$. cultures.

\begin{tabular}{|c|c|c|}
\hline & Treatments & $\begin{array}{c}\text { Total flavonoid (rutin) } \\
\mathbf{\%}(\mathbf{m g} / \mathbf{1 0 0} \mathbf{~ m g ~ e x t r a c t )}\end{array}$ \\
\hline 1 & Wild plant & $3.35 \pm 0.15$ \\
\hline 2 & Acclimated plantlet & $2.35 \pm 0.07^{*}$ \\
\hline 3 & Regenertated plantlets & $1.53 \pm 0.12^{*}$ \\
\hline 4 & 2 iP- treated plant & $0.67 \pm 0.04^{*}$ \\
\hline 5 & BAP - treated plant & $1.73 \pm 0.14^{*}$ \\
\hline 6 & Kin - treated plant & $1.57 \pm 0.07^{*}$ \\
\hline 7 & Control/multiplication & $0.96 \pm 0.05^{*}$ \\
\hline 8 & NAA- treated plant & $0.73 \pm 0.04^{*}$ \\
\hline 9 & IAA- treated plant & $1.35 \pm 0.03^{*}$ \\
\hline 10 & IBA- treated plant & $1.46 \pm 0.05^{*}$ \\
\hline 11 & Control/rooting & $0.91 \pm 0.03^{*}$ \\
\hline 12 & Callus of 2,4-D treatment & $0.85 \pm 0.03^{*}$ \\
\hline
\end{tabular}

(Note: Values are expressed by mean $\pm \mathrm{SD}, \mathrm{n}=3, *$ : significantly different from wild plant, BAP:6- benzyl aminopurine ; 2,4-D: 2,4- dichloro- phenoxy acetic acid; IAA: Indole-3acetic acid ; IBA: Indole-3-butyric acid; 2iP: 2-isopentyl adenine; Kin: Kinetin and NAA: 1- naphthalene acetic acid)

Table 9. Total flavonoids content as rutin in response to different tested elicitors in Capparis spinosa L. samples pretreated with 6- benzyl aminopurine (BAP).

\begin{tabular}{|c|l|c|}
\hline & Elicitation treatments & $\begin{array}{c}\text { Total flavonoid (rutin) } \\
\text { \% (mg/100 mg extract) }\end{array}$ \\
\hline & Wild plant & $3.35 \pm 0.15$ \\
\hline & BAP treatment & $1.73 \pm 0.14$ \\
\hline 1 & $25 \mathrm{~m} \mathrm{~mole} \mathrm{NaCl}$ & $1.92 \pm 0.03$ \\
\hline 2 & $50 \mathrm{~m} \mathrm{~mole} \mathrm{NaCl}$ & $0.94 \pm 0.03$ \\
\hline 3 & $5 \mathrm{mg} / \mathrm{L}$ sodium salicylate & None \\
\hline 4 & $10 \mathrm{mg} /$ L sodium salicylat & None \\
\hline 5 & $20 \mathrm{mg} /$ L sodium salicylate & None \\
\hline 6 & $20 \mu \mathrm{M}$ MeJA & $4.07 \pm 0.12$ \\
\hline 7 & $50 \mu \mathrm{M}$ MeJA & $5.16 \pm 0.09 *$ \\
\hline 8 & $100 \mu \mathrm{M}$ MeJA & $5.7 \pm 0.15 *$ \\
\hline 9 & $200 \mu \mathrm{M}$ MeJA & $1.57 \pm 0.21$ \\
\hline 10 & $80 \mathrm{mg} /$ L Aspergillus niger NRRL 3 & $0.62 \pm 0.04$ \\
\hline 11 & $80 \mathrm{mg} /$ L Rhizopus stolonifer NRRL 1472 & \\
\hline & & \\
\hline
\end{tabular}

(Note: BAP: 6-benzyl aminopurine and MeJA: methyljasmonate, Values are expressed by mean $\pm \mathrm{SD}, \mathrm{n}=3, *$ : significantly increase from wild plant)

HPLC analysis for different tested elicitors in Capparisspinosa L.samples pretreated with Kin: The different used elicitors were shown to have the same effect on kin. - treated microshoots like BAP treated microshoots. MeJA elicitor showed a stunning effect on the total flavonoids content (Table 10). The more the concentration of MeJA, the more the flavonoids content in the tested concentration range. The highest flavonoids content was obtained with $200 \mu \mathrm{M} / \mathrm{LMeJA}$ that which was 1.5 fold that estimated in the wild plants. Similar results ofa 2 -fold increase in flavonoids, catechin and epicatechin, of Taxus cuspidate by using MeJA as an elicitor were documented [37]. Also, other increase in phenolic compounds was reported under elicitation with MeJA [38].

Phenylalanine ammonia lyase (PAL) is the master key enzyme of flavonoids biosynthesis in plants. MeJA induced up-regulation of PAL activity that consequently increased flavonoid production [39].

\section{Conclusion}

There is no doubt that the combination of basic media composition and growth hormones intake should indeed be the first consideration
Table 10. Total flavonoids content as rutin in response to different tested elicitors in Capparis spinosa L. samples pretreated with kinetin (Kin).

\begin{tabular}{|c|l|c|}
\hline & Elicitation treatments & $\begin{array}{c}\text { Total flavonoid (rutin) \% } \\
\text { (mg/100 mg extract) }\end{array}$ \\
\hline & Wild plant & $3.35 \pm 0.15$ \\
\hline & Kin treatment & $1.57 \pm 0.07$ \\
\hline 1 & $25 \mathrm{~m} \mathrm{~mole} \mathrm{NaCl}$ & $1.58 \pm 0.02$ \\
\hline 2 & $50 \mathrm{~m} \mathrm{~mole} \mathrm{NaCl}$ & $0.81 \pm 0.03$ \\
\hline 3 & $5 \mathrm{mg} / \mathrm{L}$ sodium salicylate & None \\
\hline 4 & $10 \mathrm{mg} /$ L sodium salicylat & None \\
\hline 5 & $20 \mathrm{mg} /$ L sodium salicylate & $2.02 \pm 0.06$ \\
\hline 6 & $20 \mu \mathrm{M}$ MeJA & $2.59 \pm 0.16$ \\
\hline 7 & $50 \mu \mathrm{M}$ MeJA & $4.79 \pm 0.04 *$ \\
\hline 8 & $100 \mu \mathrm{M}$ MeJA & $4.87 \pm 0.05^{*}$ \\
\hline 9 & $200 \mu \mathrm{M}$ MeJA & $1.28 \pm 0.06$ \\
\hline 10 & $80 \mathrm{mg} /$ L Aspergillus niger NRRL 3 & $0.77 \pm 0.02$ \\
\hline 11 & $80 \mathrm{mg} /$ L Rhizopus stolonifer NRRL 1472 & \\
\hline & & Kine \\
\hline
\end{tabular}

(Note: Kin: Kinetin and MeJA: methyl jasmonate, Values are expressed by mean \pm SD, $\mathrm{n}=3, *$ :significantly increase from wild plant)

in optimal growth and secondary metabolites accumulation, but the use of elicitors as adjunct to these two basics have been used with success in this work. This enhancement was performed by using the abiotic elicitor, methyl jasmonate, that provided twofold and 1.5 foldflavonoids content from BAP and Kin -pretreated plantlets, respectively, than flavonoids content estimated in wild plants. We also report a regular platform for conservation of this endangered plant Capparisspinosa $\mathrm{L}$. through adjusted regeneration protocol which guarantees regenerates of genetic fidelity as determined by RAPD analysisand a stable chemical profile as estimated by HPLC analysis.

\section{Acknowledgements}

I would like to thank Tissue Culture Laboratories, Department of Pharmacognosy and Department of Horticulture at Faculties of Pharmacy and Agriculture, Suez Canal University.

\section{Conflict of interest}

The author declares no competing interests.

\section{References}

1. Baghiani A, Ameni D, Boumerfeg S, Adjadj M, Djarmouni M, et al. (2012) Studies of Antioxidants and Xanthine Oxidase Inhibitory Potentials of Root and Aerial Parts of Medicinal Plant Capparis Spinosa L. Am J Med Sci 2: 25-32.

2. Benzidane N, Charef N, Krache I, Baghiani A, Arrar L, et al. (2013) In vitro Bronchorelaxant Effects of Capparis Spinosa Aqueous Extracts on Rat Trachea. JAPS 3: 85-88.

3. Rajesh P, Selvamani P, Latha S, Saraswathy A, Kannan VR, et al. (2009) A review on chemical and medicobiological application of Capparidaceae Family. Phoc Rev 3: 378-387.

4. Ibrahim AK, Youssef AI, Arafa A, Ahmed SA (2013) Anti H5N1 virus flavonoids from Capparis sinaica Veill. Nat prod Res 27: 2149-2153.

5. Wahab RH, Zaghloul MS, Kamel WM, Moustafa AA (2008) Diversity and distribution of medicinal plants in North Sinai, Egypt. Afr J Environ Sci Technol 2: 157-171.

6. Musallam I, Duwayri M, Shibli RA (2011) Micropropagation of caper (Capparis spinosa L.) from wild plants. Funct Plant Sci Biotechnol 5: 17-21.

7. Chalak L, Elbitar A (2006) Micropropagation of Capparis spinosa L. subsp. Rupestris by nodal cuttings. Indian J. Biotechnol 5: 555-558.

8. Carra A, Sajeva M, Abbate M (2012) In vitro plant regeneration of caper (Capparis spinosa L.) from floral explants and genetic stability of regenerants. Plant Cell Tiss Organ Cult 109: 373-381. 
9. Namdeo AG (2007) Plant Cell Elicitation for Production of Secondary Metabolites: A Review. Phoog Rev 1: 69-79.

10. Govarthanan M, Guruchandar A, Arunapriya S, Selvankumar T, Selvam K, et al. (2011) Genetic variability among Coleus sp. studied by RAPD banding pattern analysis. Int $J$ Biotechnol Mol Biol Res 2: 202-208.

11. Ibenthal WD (2010) In vitro propagation protocol for prentation of some wild medicinal plants genotypes grown in Sinai, Egypt. The Sixth Inter Conf of Sustain Agric And Develop Fayoum, Egypt.

12. Abu Khallaf G, Arafeh R (2010) Capparis spinosa L., "caper": In vitro propagation, Callus culture and secondary metabolites production and bioassay. $2^{\text {nd }}$ conference of biotechnology research and application, Palestine.

13. Khattab S, El Sherif F (2011) Effect of growth regulators on Carpobrotus edulis rapid micropropagation and molecular analysis. $\mathrm{J} \mathrm{Am} \mathrm{Sci} \mathrm{7:} \mathrm{511-520.}$

14. Zidani S, Ferchichi A, Chaieb M (2005) Genomic DNA extraction method from pearl millet (Pennisetum glaucum) leaves. Afr J Biotechnol 4: 862-866.

15. El Sherif F, Khattab S, Ibrahim AK, Ahmed SA (2013) Improved silymarin content in elicited multiple shoot cultures of Silybum marianum L. Physiol Mol Biol Plants 19: 127-136.

16. Thiem B, Krawczyk A (2010) Enhanced isoflavones accumulation in methyl jasmonatetreated in vitro cultures of kudzu (Pueraria lobata Ohwi). Kerva Polonica 56: 48-56.

17. Vernosefadrani MT, Raberi AN, Nosrati SZ (2009) Optimization of in vitro culture for Gerbera cv. Tropic Blend. Sapling Seed 2: 389-401.

18. Fotso DT, Mbouna D, Omakolo ND (2007). In vitro regeneration of Ricinodendron heudelotii. Cashiers Agriculture 16: 31-36.

19. Pardo A, Michelangeli C, Mogollón N, Alvarado YG (2008) In vitro regeneration of Billbergia rosea Hortus ex beer via shoot tips. Bol Centro Invest Biol 42: 491-505.

20. Haripyaree A, Guneshwor K, Sunitibala H, Damayanti M (2011) In vitro propagation of Citrus megaloxycarpa. EEB 9: 129-132.

21. Mamun AN, Islam R, Reza MA, Joadar OI (1996) In vitro differentiation of plantlet of tissue culture of Samonea saman. Plant Tissue Cult 6: 1- 5

22. H Sherkar HD, Chavan AM (2014) Effect of 2,4-D, BAP and TDZ on Callus Induction and Shoot regeneration in Potato. Sci Res Repot 4: 101-105.

23. Huetteman CA, Preece JE (1993) Thidiazuron: a potent cytokinin for woody plant tissue culture. Plant Cell Tiss Organ Cult 33: 105-119.

24. Thomas TD (2003) Thidiazuron induced multiple shoot induction and plant regeneration from cotyledonary explants of mulberry. Biol Plant 46: 529-533.
25. Faisal M, Anis M (2005) Shoot multiplication in Rauvolfia tetraphylla L. using thidiazuran. Plant Cell Tiss Organ Cult 80: 187-190.

26. Martins M, Sarmento D, Oliveira MM (2004) Genetic stability of micropropagated almond plantlets as assessed by RAPD and ISSR markers. Plant Cell Rep 23: 492-496

27. Venkatachalam L, Sreedhar RV, Bhagyalakshmi N (2007) Genetic analysis of micropropagated and regenerated plantlets of banana as assessed by RAPD and ISSR markers. In Vitro Cell Dev Biol 43: 267-274

28. Bhowmik SS, Kumaria S, Rao SR, Tandon P (2009) High frequency plantlet regeneration from rhizomatous buds in Mantisia spathulata Schult. and Mantisia wengeri Fischer and analysis of genetic uniformity using RAPD markers. IJEB 47:140146

29. Parida R, Mohanty S, Nayak S (2011) Evaluation of genetic fidelity of in vitro propagated greater galangal (Alpinia galanga 1 .) using DNA based markers. Int $J \mathrm{Pl}$ An and Env Sci 1: 123-133.

30. Drouen AH, Billiet HH, Galan LD (1984) Dual-wavelength absorbance ratio for solute recognition in liquid chromatography. Anal Chem 56: 971-978

31. Law KH, Das NP (1987) Dual-wavelength absorbance ratio and spectrum scanning techniques for identification of flavonoids by high-performance liquid chromatography. J Chromatogr 388: 225-233.

32. J Reijenga JC, Verheggen Th P, Everaerts FM (1983). Dual-wavelength UV-absorption detection in capillary isotachophoresis. J Chromatogr 267: 75-84

33. Sangwan NS, Farooqi AH, Shabih F, Sangwan RS (2001) Regulation of essential oil production in plants. Plant Growth Regul 34: 3-21.

34. Indu S, Vijaya L, Meeta B, Jossy V, Naresh C (2013) Production of flavonoids in callus culture of Anthocephalus indicus A. Rich. Asian J Plant Sci 12: 40-45.

35. Krishna S, Renu S (2013) Isolation and identification of flavonoids from Cyperus rotundus L. in vivo and in vitro. J Drug Deliv Ther 3: 109-113.

36. Ghasemzadeh A, Jaafar HZ (2012) Effect of salicylic acid application on biochemical changes in ginger (Zingiber officinale Roscoe). J Med Plants Res 6: 790-795.

37. Bulgakov VP, Tchernoded G, Veselova M, Fedoreyev S, Muzarok T, et al. (2011) Catechin production in cultured cells of Taxus cuspidata and Taxus baccata. Biotechnol Lett 33: 1879-1883.

38. Kim HJ, Fonseca JM, Choi JH, Kubota C (2007). Effect of methyl jasmonate on phenolic compounds and carotenoids of romaine lettuce (Lactuca sativa L.). Plant Biochem 55: 10366-10372.

39. Wang J, Qian J, Yao L, Lu Y (2015) Enhanced production of flavonoids by methyl jasmonate elicitation in cell suspension culture of Hypericum perforatum. BRBP 2: 1-9.

Copyright: $\odot 2017$ Goda SM. This is an open-access article distributed under the terms of the Creative Commons Attribution License, which permits unrestricted use, distribution, and reproduction in any medium, provided the original author and source are credited. 